\title{
Is information quality on a shopping website a deciding factor for South African consumers?
}

\author{
Yu-ting Hung \\ Michael C Cant \\ University of South Africa, South Africa \\ Department of Marketing and Retail Management
}

\section{Keywords}

Information quality, online shopping, online retailers, South Africa

\begin{abstract}
Since the development of the Internet and the web, various aspects of society have changed, including the way business is conducted, how information is shared and gathered, and how goods and services are purchased (Shanthi EKannaiah, 2015:14). Consumers are now able to shop online with an abundance of information readily available at their fingertips. Particularly with the increasing use of social media which has influenced a number of online shopping activities namely finding ideas, researching goods, looking for promotions and sharing purchases online (Morisson, 2014). The purpose of this study was to explore the influence of information quality factors on online shopping. The results of the study could assist online retailers to better target consumers by having a better understanding of the influence of information quality on their online shopping. Primary data was collected by means of self-administered Internet surveys. Respondent demographics and online shopping activity were firstly identified, followed by the influence of information quality factors. The research found that all information quality factors influence online shopping, however secureness was the most influential factor. By having a thorough understanding of the influence of information quality for online shopping, online retailers can ensure that consumers' cost of searching for goods are reduced.
\end{abstract}

Corresponding author: Michael C Cant

Email address for corresponding author: mailto:cantmc@unisa.ac.za

First submission received: 7th February 2017

Revised submission received: 24th March 2017

Accepted: 18th April 2017

\section{Introduction}

Online shopping is the process of purchasing goods and services over the Internet by shoppers at their own leisure (Jusoh \&Ling, 2012:223). Even though there are a number consumers who avoid shopping online, the activity has increased in popularity and is perceived as an important medium for shopping(Keisidou, Sarigiannidis \&Maditinos, 2011:31). According to Nagra and Gopal (2013:1) online shopping is the future of shopping as more companies begin using the Internet to sell their products or services. The Internet has changed the shopping environment by ensuring that consumers have an abundance of information available to them (Mazaheri, Richard\& Laroche, 2011:975). According to Lin (2007:363) receiving current, accurate and useful information is one of the key advantages of shopping online. It has been found that the availability of information not only significantly reduces consumers' cost of search, but also influences their intentions to shop online (Hwang, Preiser-Houy \& Shang, 2012:338).

Previous research in the South African context has mainly focused on online shopping behaviour, online shopping orientation, determinants of online shopping satisfaction, perceived benefits and barriers of online shopping and products or service purchased online (De Swardt \& 
Wagner, 2008; Tapson, 2009; Croker, 2009; Mohanlal, 2011; Botha, 2014; Kempen, Kasambala \& Toerien, 2015; Cunningham, 2015; Snyman, 2015). This study focuses on the influence of information quality factors of a website. By gaining a better understanding of the influence of information quality factors, it could assist retailers in improving their website designs and marketing and communication strategies targeting consumers, as well as assist in developing the online retailing market in South Africa.

In the subsequent section of the study, the literature review is discussed. This is then followed by the research objectives and research methodology that was utilised for this study. The research findings, recommendations and concluding remarks are then discussed to conclude the study.

\section{Literature review}

\subsection{Overview of online shopping}

Over the years E-commerce has developed quickly in a short amount time. E-commerce refers to conducting business over the web and is comprised of online shopping, electronic payments, online banking and e-marketing(Bothma \& Gopaul, 2015:13). The most popular and commonly used aspect of E-commerce is online shopping which has increased significantly and has become an accepted form of assisting consumers in purchasing goods and services (Bourlakis, Papagiannidis \&Fox, 2008:64). Online shopping consists of searching, browsing and buying online. According to Song, Baker, Lee and Wetherbe (2012:223) providing detailed descriptions of the goods with pictures and pricing information decreases uncertainty and hesitation in buying. However, even though there are consumers who are still reluctant to buy online, many search online for specific goods and browse online by casually looking for goods which they may or may not wish to buy (Jeng, 2013:772; Elkhatib, Killick, Mu \&Race, 2014:964). The Internet enables consumers to conduct in-depth searches and comparisons that is efficient, convenient and inexpensive (Bagdoniene \&Zemblyte, 2009:367).

A number of authors have adapted and used information system (IS) research as a basis to determine the quality of a shopping site (Loiacono, Watson \& Goodhue, 2002; Barnes \& Vidgen, 2002; Webb \&Webb, 2004). The Internet can be described as a communication and IS phenomenon, therefore accepted and tested IS models can be adapted to make sure an E-commerce website (Delone \& McLean, 2003; Sharkey, Scott \&Acton, 2010:2). This research therefore used information quality factors identified by Delone and McLean IS success model (2003) as the basis for this research.

\subsection{Information quality factors}

According to Delone and McLean (2004:25) information quality captures the content of the online system which should be personalised, complete, relevant, easy to understand and secure. Information quality is important because it ensures user satisfaction, business profitability, improved decision making and the use of the system (Bai, Law \&Wen, 2008:391). Information quality can therefore be seen as a marketing tool that ensures the smooth execution of online shopping transactions by providing users with accurate, informative and relevant information in a timely manner (Kim \& Niehm, 2009:223). The various factors of information quality will now be discussed.

\section{- Personalisation}

According to Sharma, Alexander, Hoand Arasu (2013:38) personalisation entails a website providing recommendations based on the users' preference and interest. Whereas, Lawless, O'Connor and Mulwa (2010:1) refers to personalisation as the most suitable response for an individual user's needs. It has been found that personalisation can assist online retailers by reducing the information overload of consumers, conveying more convincing messages and building relationships with consumers(Liang, Li \& Turban, 2009:2).A growing trend for online retailers to use 
specific software algorithms that display goods to a user based on their preferences (Harker \&Riccio, 2012:10).

\section{- Completeness}

Al-Mamary, Shamsuddin and Aziati (2014:9) state that completeness is the extent to which information is available and sufficient in depth and breadth for the task at hand. In essence, completeness refers to whether all of the data or information is present (Gorla, Somers and Wong, 2010:213). According to Kim, Galliers, Shin, Ryoo and Kim (2012:377) in order for online business to attract and retain users, it is crucial that they provide users with complete information throughout the purchasing process. The availability and completeness of information is essential as it ensures that users are able to make competent and informed decisions about their online purchases which influences their attitudes and buying intentions (Cheung \&Lee, 2005:8).

- Relevance

Bizer (2007:18) states that relevancy refers to the extent to which information is helpful and applicable for a specific task. Providing relevant information to online shoppers decreases uncertainties they may have and influences their evaluation of the website and purchasing decisions (Cheung \&Lee, 2005:8). Kuo and Chen (2011:255) state that people are more likely to purchase from websites that provide adequate and relevant information. Furthermore, people who do not purchase online, still search for product information on the Internet and use it as a reference for traditional brick-by-mortar shopping which emphasises the importance of providing relevant information (Kuo \& Chen, 2011:255).

\section{- Ease of understanding}

The fourth factor of information quality dimension is being easy to understand which refers to the extent which information is clear without ambiguity and easily comprehended (Huang \& Benyoucef, 2013:249). Information that is easy to understand assist people to make better decisions and leads to more sales because people that are confused are less likely to make any purchases (Morgan, 2014). Therefore, it is crucial for online retailers to present information that is simple, clear and to the point (Patel, 2011).

\section{- $\quad$ Secureness}

The fifth factor of information quality dimension is secureness which refers to a shopping site ensuring the security of payments and ensuring the privacy of any information that is shared (Kim \&Lennon, 2013:34). Online shoppers are required to provide personal information in order to complete an online purchase (Kim et al., 2012:377; Dai, Forsythe \&Kwon, 2014:15). In order to build trust and long-term relationships with online shoppers, it is crucial to ensure privacy and security measures are in place (Safari, 2012:60-61).

\section{Research objectives and methodology}

The main purpose of the study was to explore website information quality factors influencing online shopping in the South African context. Primary data was collected from South African consumers in order to sufficiently address the research problem. To determine the influence of the factors, the data was quantified and analysed through frequency counts. The sampling methodology made use of non-probability, convenience sampling, which allowed the researcher to gather the data efficiently. An Internet-based questionnaire was administered to consumers via social media platforms and a total of 123 usable responses were used for the analysis.

\section{Research findings and discussions}

In the subsequent sections, the demographic and online shopper profile of the sample is provided, followed by discussions on service quality factors that influence online shopping. 


\subsection{Demographic profile}

Table 1 below summarises the demographic profile of the respondent group. The respondent group was dominated by female respondents $(67.5 \%)$ where more than half $(57.7 \%)$ of the respondents are between the ages of $26-35$ years old. Roughly a third (32.5\%) of the respondents has an Honours degree and a large proportion (70.7\%) of the respondents is permanently employed.

Table 1: Demographic profile

\begin{tabular}{|c|c|c|c|}
\hline \multirow{3}{*}{ Gender } & & Count & $\%$ of Total \\
\hline & Female & 83 & 67.5 \\
\hline & Male & 40 & 32.5 \\
\hline \multirow[t]{4}{*}{ Age group } & $18-25$ & 33 & 26.8 \\
\hline & $26-35$ & 71 & 57.7 \\
\hline & $36-45$ & 9 & 7.3 \\
\hline & $46-65$ & 10 & 8.1 \\
\hline \multirow[t]{9}{*}{ Highest qualification } & Other & 1 & 0.8 \\
\hline & Doctoral degree & 1 & 0.8 \\
\hline & Master's degree & 19 & 15.4 \\
\hline & Honours degree & 40 & 32.5 \\
\hline & Postgrad diploma & 2 & 1.6 \\
\hline & Bachelor's degree & 32 & 26.0 \\
\hline & Diploma or advanced certificate & 15 & 12.2 \\
\hline & Higher certificate & 1 & 0.8 \\
\hline & Matric & 12 & 9.8 \\
\hline \multirow[t]{6}{*}{ Employment status } & Other & 6 & 4.9 \\
\hline & $\begin{array}{l}\text { Unemployed and not looking for } \\
\text { work }\end{array}$ & 1 & 0.8 \\
\hline & Unemployed and looking for work & 6 & 4.9 \\
\hline & Part time employed & 4 & 3.3 \\
\hline & Permanently employed & 87 & 70.7 \\
\hline & Self employed & 19 & 15.4 \\
\hline
\end{tabular}

The respondent group mostly $(85.4 \%)$ accessed the Internet a few times almost every hour and roughly half $(45.5 \%)$ shop online at least once per month

\subsection{Information quality factors influencing online shopping}

This question in the survey was in the form of a 5-point Likert scale which aimed to determine the influence of each information quality factor affecting South African consumers when shopping online. The respondents were asked to indicate the extent to which they agreed or disagreed with statements describing information quality factors influencing online shopping. For simplicity, the levels of agreement were combined to form a 3-point scale where strongly disagree and disagree were combined as one and on the other hand, agree and strongly agree were combined as one.

The first factor of information quality is personalisation which refers to a site providing suggestions and recommendations based on the users' preferences and interests. Figure 1 provides the results for the influence of the factor 'personalisation' on online shopping. For all the statements, responses are positive with the respondents agreeing or strongly agreeing that the factor 'personalisation' influences their online shopping. A shopping site providing accurate recommendations was seen as the most agreed upon statement $(69.9 \%$ or 86$)$. The results indicate that online retailers should be able to provide relevant suggestions to online shoppers. When accurate suggestions are provided, online shoppers tend to spend less time searching and browsing, and this could lead to a quicker check-out process. 


\section{Figure 1: The influence of personalisation on online shopping $(n=123)$}

A shopping site that suggests products/services based on my interests influences me to shop...

A shopping site that suggests products/services I am likely to buy influences me to shop online

A shopping site that suggests products/services based on my purchasing histor'y influences me. .

A shopping site that provides accurate recommendations as to what I am looking for.

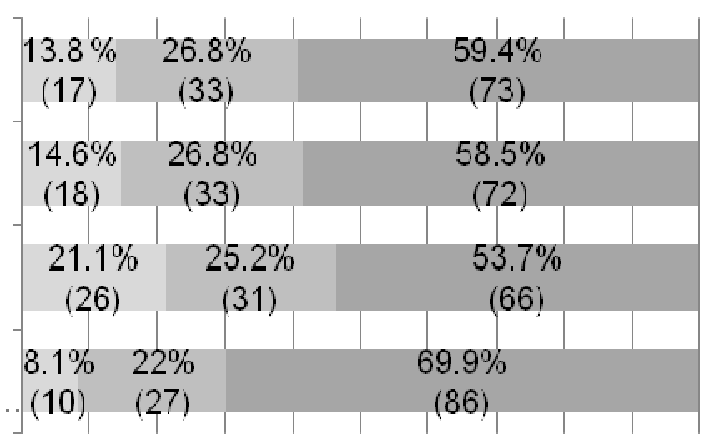

Strongly disagree and disagree $\quad$ Neither disagree or agree $\quad$ Agree and strongly agree

The next factor of information quality is 'completeness'. Figure 2 provides the results for the influence of the factor 'completeness' on online shopping. For all the statements, responses are positive as most of the respondents agree or strongly agree that the factor 'completeness' influences their online shopping. Providing comprehensive information regarding products or services was considered as the most agreed upon statement (93.5\% or 115). It appears from the results that online retailers should provide comprehensive information regarding all aspects of their business. Online shoppers could view this transparency as a sign that they can trust the retailer which could lead to increased sales and more specifically to encouraging non-online shoppers to shop online.

Figure 2: The influence of completeness on online shopping $(n=123)$

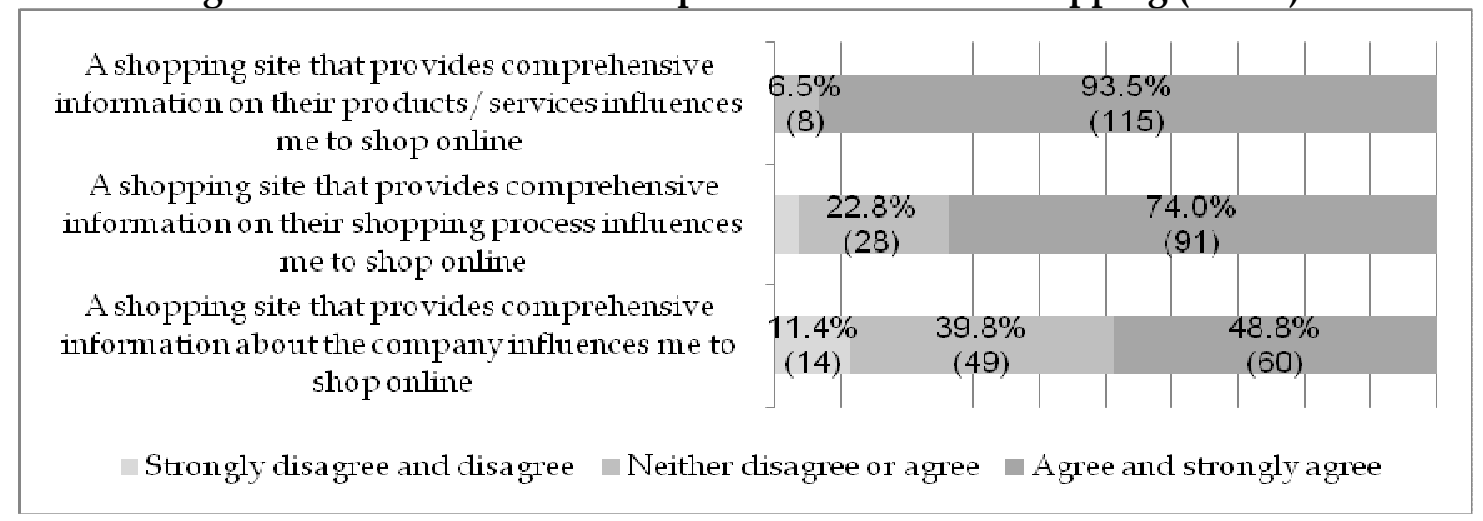

The next factor of information quality is 'relevancy'. Figure 3 provides the results for the influence of the factor 'relevancy' on online shopping. For all the statements, responses are overwhelmingly positive with most of the respondents agreeing or strongly agreeing that the factor 'relevancy' influences their online shopping. A shopping site that provides relevant information is seen as the most agreed upon statement (91.9\% or 113). It appears from the results that online retailers should provide all the necessary information regarding the products or services. Similar, to the previous sections discussed, with all the essential information readily available to online shoppers, they not only save time going through the online shopping process but are also more inclined to trust the online retailer.

The next factor of information quality is 'ease of understanding'. Figure 4 summarises the results for the influence of the factor 'ease of understanding' on online shopping. For all the statements, responses are positive with most of the respondents agreeing or strongly agreeing that the factor 'easy to understand' influences their online shopping. Having clear instructions and providing information that is clear in meaning (unambiguous) are seen as the most agreed upon 
statements $(88.6 \%$ or 109). The results indicate that online shopping sites should contain unambiguous language and instructions. Again, this could not only lead to increased sales but also encourage more non-online shoppers to participate as they fully understand the process of online shopping.

Figure 3: The influence of relevancy on online shopping $(n=123)$

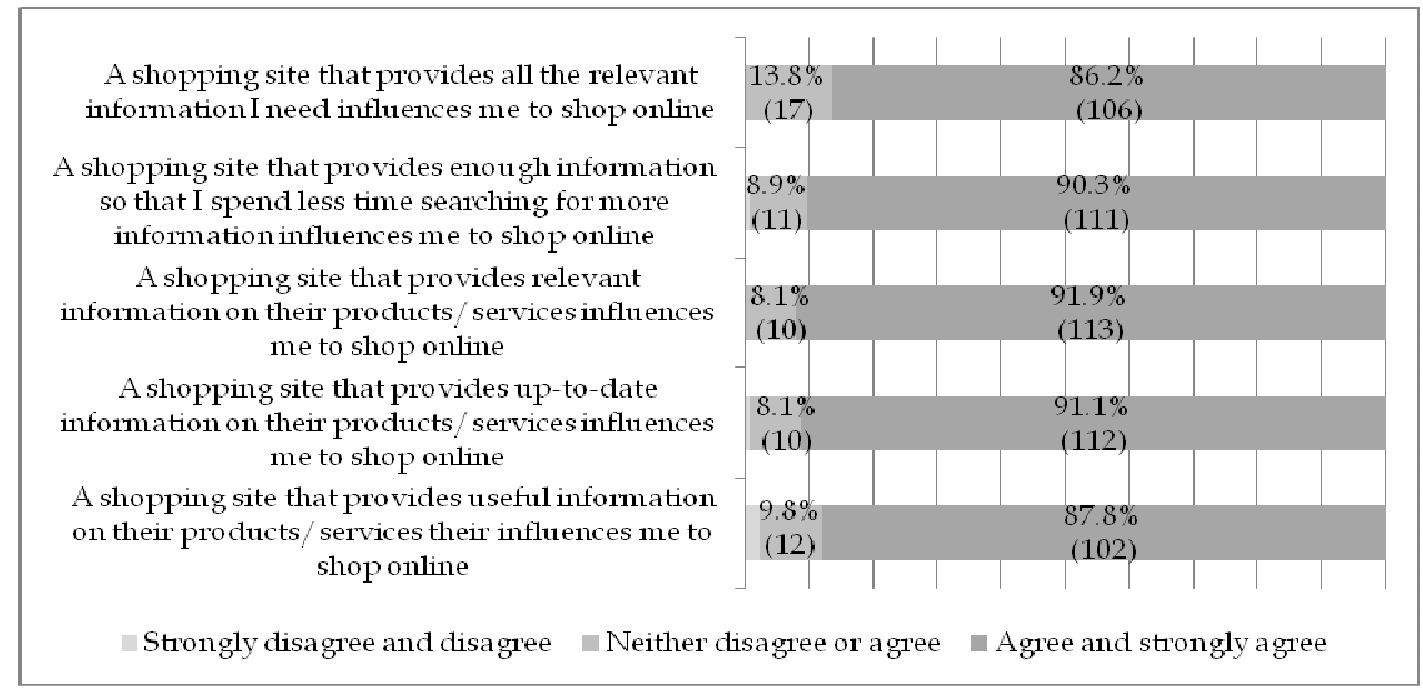

Figure 4: The influence of ease of understanding on online shopping $(n=123)$

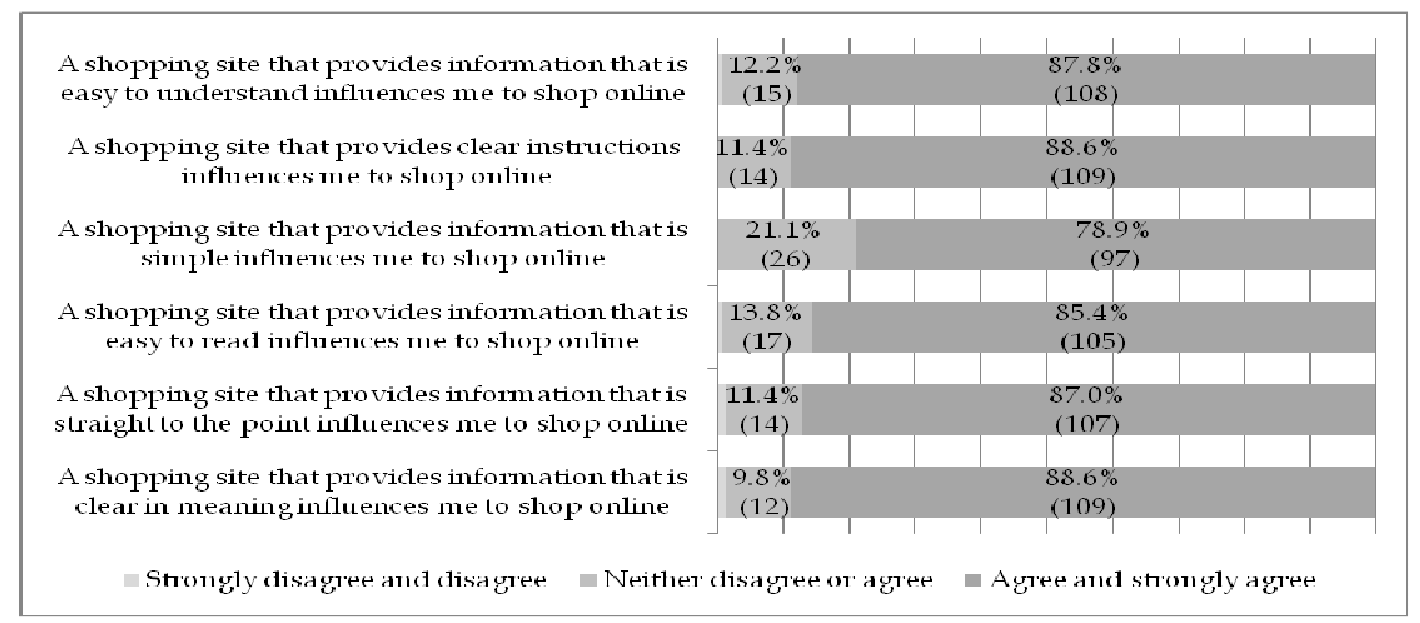

The last factor of information quality is 'secureness'. Figure 5 provides the results for the influence of the factor 'secureness' on online shopping. For all the statements, responses are overwhelmingly positive with the majority of the respondents agreeing or strongly agreeing that the factor 'secureness' influences their online shopping. The protection of personal information is considered as the most agreed upon statement (96.6\% or 119). It appears from the results that online shoppers require online retailers to protect them during the online shopping process. Therefore, online retailers should communicate to online shoppers the different measures that they have in place to protect them and provide suggestions on how they can avoid fraudulent activities and scams. 
Figure 5: The influence of secureness on online shopping $(\mathrm{n}=123)$

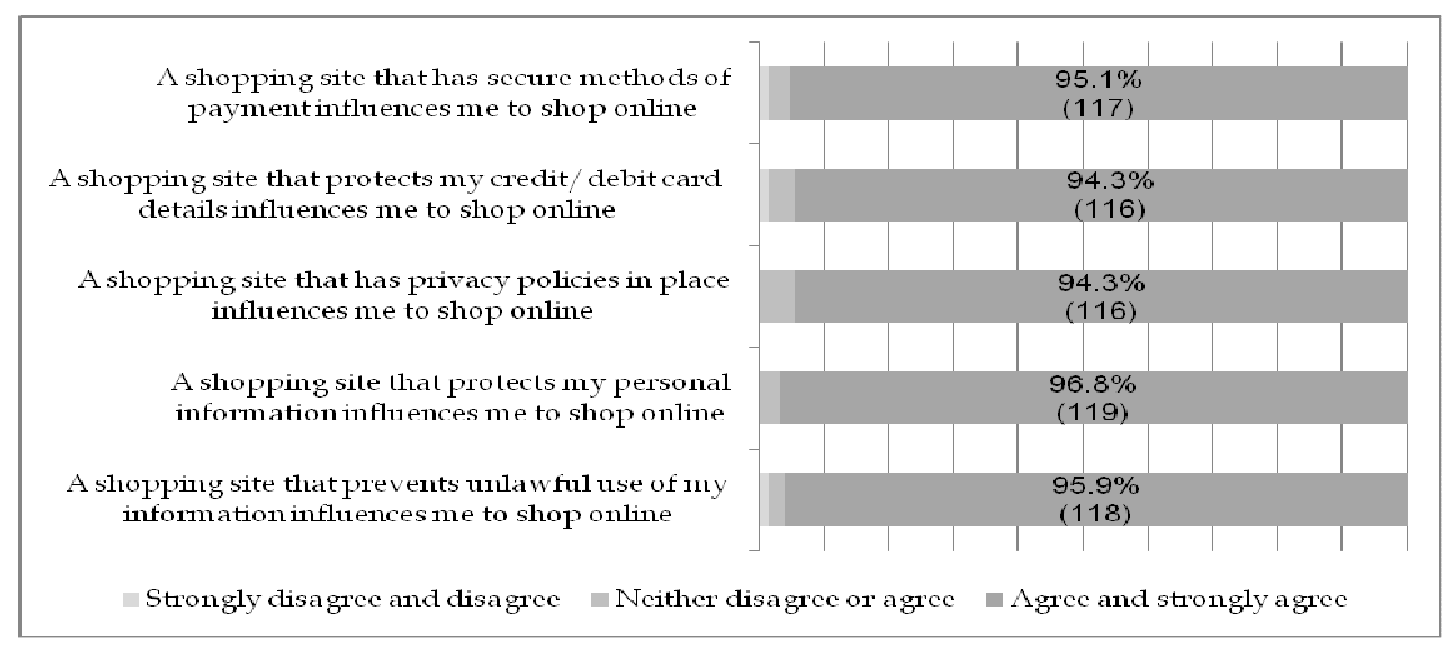

\subsection{Reliability analysis and mean scores}

Reliability analysis or internal consistency measures similarity of responses for an item (Scherbaum \& Schockley, 2015:59). In order for a scale to be considered as reliable, a minimum Cronbach's alpha value of 0.7 is needed (Wiid \&Diggines, 2013:238). As shown in Table 2, Cronbach's alpha values ranging between 0.709 and 0.935 were recorded for the various information quality factors.

According to Malhotra (2010:486) the mean, also referred to as the average value, is the sum of all elements in a dataset divided by the number of elements. All of the mean values are higher than the middle value (3) of the scale (from 1 to 5) used to express the extent to which a respondent agreed with the statements, indicating that most of the respondents agreed that information quality factors influence them to shop online.

Table 2: Cronbach's alpha values for information quality factors

\begin{tabular}{|c|c|c|c|c|}
\hline Factor construct & Items & $\begin{array}{c}\text { Cronbach's } \\
\text { alpha }\end{array}$ & $\begin{array}{c}\text { Average mean } \\
\text { score }\end{array}$ & $\begin{array}{c}\text { Standard } \\
\text { deviation }\end{array}$ \\
\hline Personalisation & 4 & 0.888 & 3.64 & 0.844 \\
\hline Completeness & 3 & 0.709 & 4.00 & 0.647 \\
\hline Relevance & 5 & 0.860 & 4.27 & 0.532 \\
\hline Ease of understanding & 6 & 0.935 & 4.23 & 0.609 \\
\hline Secureness & 5 & 0.877 & 4.72 & 0.494 \\
\hline
\end{tabular}

It can be seen that secureness in information quality scored the highest $(M=4.72, S D=0.494)$. This indicates that a shopping site should address all information quality factors, however focusing on the secureness of information quality which ensures securing users' personal information. These should be viewed as fundamental factors which online retailers need to address in order to ensure that shoppers make use of their shopping sites.

\section{Conclusion and recommendations}

The primary purpose of a website is to provide information to its users and in today's world consumers have access to a vast amount of information from a variety of sources (Ghaffari \& Ashkiki, 2015:517; Sanje \& Senol, 2012:114). According to Milan, Bebber, De Toni and Eberle (2015:112) consumers have changed the way in which they purchase goods and services in terms of how they search and compare offerings and their prices before buying the best option. When selecting and using information, consumers want the best information available for their purpose 
(Mai, 2013:675) and in this instance information relating to the products and services that they shop for online. The research found that respondents agreed or strongly agreed that information quality factors influence them to shop online. It is therefore recommended that online retailers ensure that their shopping sites address all information quality factors influencing online shopping.

The most agreed upon factor being secureness. According to Niranjanamurthy and Chahar (2013:1) security is one of the main concerns for consumers and organisation making use of Ecommerce. Online retailers should therefore protect and prevent the unlawful use of the shoppers' personal information, offer secure methods of payment and protect their credit/debit card details, and have privacy policies in place. $\mathrm{Wu}$, Huang, Yen and Popova (2012:890) state that a privacy policy clarifies how the shopping site uses the personal information and also provides information regarding the security of the site. The online retailer should also use reliable encryption protection software to protect the users and their information, use reputable third party payment systems that require authentication from the shopper when purchasing, and provide details regarding this in its privacy policy. Furthermore, the privacy policy should indicate for what and how their personal information will be used.

The following most agreed upon factor is relevance. Lobaugh, Simpson and Ohri (2014:11) state that consumers want relevant information on a shopping site and during the online shopping process. The online retailer should therefore provide relevant, up-to-date and useful information on the products and services offered and make available sufficient and all relevant information that saves the user time on searching. Depending on the product or service, varying information should be provided, however it is important to provide the basics which are clear descriptions, the price and availability of the goods.

The next factor is ease of understanding. As stated previously, if the shopper can easily understand what is expected of them going through the online shopping process, then they will more likely shop online. Online retailers therefore need to provide clear instructions and information that is clear in meaning, easy to understand, to the point, easy to read and simple. Furthermore, clear descriptions of the goods should also meet these criteria in order to ensure that consumers know exactly what they will receive.

The subsequent factor is completeness. According to Al-Maghrabi, Dennis, Halliday and BinAli (2011:42) gathering information by consumers is a crucial aspect of online shopping. Online retailers should therefore provide comprehensive information on their products and services and on the shopping process. As stated previously, when consumers have all the necessary information, they are able to make informed decisions which influence their attitudes and purchasing intention.

The final factor is personalisation. K3 Retail (2016:3) state that personalisation is the future of retailing and retailers should make their products and services relevant to each consumer. Online retailers should therefore provide accurate recommendations, suggest products and services based on consumers' interests, what they will likely buy and based on their purchasing history. Online retailers should try target consumers at an individual level and not merely group segmentation.

\section{Research limitations and direction for future research}

Due to the researcher making use of non-probability convenience sampling and having a small sample, the results could not be generalised to the larger South African population. However, as the purpose of the study was not to provide conclusive results but to rather explore the topic at hand in order to transfer the results and to identify suggestions for future research. Furthermore, selfadministered Internet-based surveys were utilised whereby respondents could have misinterpreted the questions. However, the researcher conducted a pre-test where revisions were made in order to ensure that the questions were clear and easy to understand.

\section{References}

Al-Maghrabi, T., Dennis, C., Halliday, S.V. \& BinAli, A. 2011.Determinants of customer continuance 
intention of online shopping. International Journal of Business Science and Applied Management, 6(1):41-65.

Al-Mamary, Y.H., Shamsuddin, A. \&Aziati, N. 2014.The relationship between system quality, information quality and organisational performance. International Journal of Knowledge and Research in Management and E-commerce, 4(3):7-10.

Bagdoniene, L. \& Zemblyte, J. 2009. Online shopping motivation factors and their effect on lithuanian consumers online shopping factors: review of some studies results. Economics $\mathcal{E}$ Management, 14(2009):367-374.

Bai, B., Law, R. \& Wen, I. 2008. The impact of website quality on customer satisfaction and purchase intentions: evidence from Chinese online visitors. International Journal of Hospitality, 27(2008):391-402.

Barnes, S. \& Vidgen, R., 2002.An integrative approach to the assessment of e-commerce quality. Journal of Electronic Commerce Research, 3(3):114-127.

Bizer, C. 2007.Quality-Driven Information Filtering in the Context of Web-Based Information Systems.Mcom Thesis. Freie Universitat Berlin.

Botha, D.H. 2015. The determinants of South African consumers' online shopping satisfaction. Mcom Thesis. Pretoria: University of Pretoria.

Bothma. C. \& Gopaul, M. 2015. E-marketing in the South African context. Cape Town:Juta.

Bourlakis, M., Papagiannidis, S. \& Fox, H. 2008. E-Consumer Behaviour: Past, Present and Future Trajectories of an Evolving Retail Revolution. International Journal of E-Business Research. 4(3):64-76.

Cheung, C.M.K. \& Lee, M.K.O. 2005.Research framework of consumer satisfaction with Internet shopping. Sprouts: Working Papers on Information System, 5(26):1-19.

CP-Africa. 2013. Infographic: E-commerce in Africa - preferences of African consumers in Nigeria, Kenya and South Africa. CPAfrica.[Online] Available from: http://www.cpafrica.com/2013/06/03/e-commerce-in-africa/ [Accessed: 2013-09-30].

Croker, A.D. 2009. Customer satisfaction in the online grocery shopping market. Mcom Thesis. University of South Africa.

Cunningham, N. 2015. Consumers perception of shopping channel attributes and risk factors influencing apparel purchases. Mcom Thesis. University of Johannesburg.

Dai, B., Forsythe, S. \& Kwon, W.S. 2014. The impact of online shopping experience on risk perception and online purchase intentions: does product category matter? Journal of Electronic Commerce Research, 15(1):13-24.

De Swardt, M. \& Wagner, C. 2008. Factors influencing the choice to shop online: a psychological study in a South Africa context. New Voices in Psychology, 4(2):68-82.

DeLone, W.H. \& McLean, E.R. 2003. The DeLone and McLean model of information systems success: A ten-year update. Journal of Management Information Systems, 4(19):9-30.

DeLone, W.H. \& McLean, E.R. 2004. Measuring e-Commerce Success: Applying the DeLone\& McLean Information Systems Success Model. International Journal of Electronic Commerce, 9(1):31-47.

Elkhatib, Y., Killick, R., Mu, M. \& Race, N. 2014. Just Browsing?: Understanding User Journeys in Online TV. Proceedings of the 22Nd ACM International Conference on Multimedia. 965-968.

Ghaffari, A. \&Ashkiki, M.F. 2015.The impact on the quality of the website to buy online customers.Journal of Applied Environmental and Biological Sciences, 5(11S):516-526.

Gorla, N., Somers, T.M. \& Wong, B. 2010.Organisational impact of system quality, information quality and service quality. Journal of Strategic Information Systems, 19(2010):207-228.

Harker, S. \&Riccio, J. 2012.The future of retail - consumer adaptive retailing. PwC. [Online] Available from: http://www.pwc.com.au/industry/retail-consumer/assets/ Digital-Media-PaperJul12.pdf [Downloaded: 2014-05-24]. 
Huang, Z. \&Benyoucef, M. 2013. From e-commerce to social commerce: a close look at design features. Electronic Commerce Research and Applications, 12(4):246-259.

Hwang, D., Preiser-Houy, L. \& Shang, R.A. 2012. A comprehensive framework for online store functionalities. Issues in Information Systems, 13(2):336-345.

Jeng, S. 2013. Online gift-searching: gift-giving orientations and perceived benefits of searching. Online Information Review, 37(5):771-786.

Jusoh, Z.M. \& Ling, G.H. 2012. Factors influencing consumers' attitude towards e-commerce purchases through online shopping. International Journal of Humanities and Social Science, 2(4):223-230.

Katawetawaraks, C. \& Wang, C.L. 2011. Online Shopper Behavior: influences of Online Shopping Decision. Asian Journal of Business Research. 1(2):66-74.

Keisidou, E., Sarigiannidis, L. \& Maditinos, D. 2011. Consumer characteristics and their effect on accepting online shopping, in the context of different product types. International Journal of Business Science and Applied Management, 6(2):31-51.

Kempen, E., Kasambala, J. \&Toerien, E. 2015.A conceptual framework of e-fashion shopping intent.The Retail and Marketing Review, 11(1):23-43.

Kim, C., Galliers, R.D., Shin, N., Ryoo, J.H. \& Kim, J. 2012. Factors influencing Internet shopping value and customer repurchase intention. Electronic Commerce Research and Application, 11(4):374-387.

Kim, H. \&Niehm, L.S. 2009.The impact of website quality on information quality, value and loyalty intentions in apparel retailing. Journal of Interactive Marketing, 23(2009):221-233.

Kim, J. \& Lennon, S.J. 2013. The effects of reputation and website quality on online consumers' emotion, perceived risk and purchase intention: based on the stimulus-organism-response model. Journal of Research in Interactive Marketing, 7(1):33-56.

Kuo, H. \& Chen, C. 2011.Application of quality function deployment to improve the quality of Internet shopping website interface design. International Journal of Innovative Computing, Information and Control, 7(1):253-268.

K3 Retail. 2016. Personalisation: why it's the future of retail. K3 Retail. [Online] Available from: www.k3retail.com/do_download/.../K3_Personalisation_WP_MRCH

15_sprd_1-4.pdf [Downloaded: 2017-01-24].

Lawless, S., O'Connor, A. \&Mulwa, C. 2010.A proposal for the evaluation of adaptive personalised information retrieval.CIRSE '10 Workshop on Contextual Information Access, Seeking and Retrieval Evaluation, 28th March, 2010, Milton Keynes, UK.

Liang, T.P., Li, Y.W. \& Turban, E. 2009. Personalised services as empathic responses: the role of intimacy. PACIS 2009 Proceedings.

Lin, H.-F. 2007. The Impact of Website Quality Dimensions on Customer Satisfaction in the B2C Ecommerce Context. Total Quality Management E Business Excellence. 18(4):363-378.

Lobaugh, K., Simpson, J. \&Ohri, L. 2014. The new digital divide: retailers, shoppers and the digital influence factor. Deloitte Development LLC.[Online] Available from:

https://www2.deloitte.com/content/dam/Deloitte/us/Documents/consumer-business/us-rdthenewdigitaldivide-041814.pdf [Downloaded: 2017-01-23].

Loiacono, E.T., Watson, R.T. \&Goodhue, D.L. 2002.WEBQUAL: A measure of website quality. American Marketing Association, 13(2002):432:438.

Mai, J. 2013. The quality and qualities of information. Journal of the American Society for Information Science and Technology, 64(4):675-688.

Malhotra, N.K. 2010.Marketing research: An applied orientation. $6^{\text {th }}$ edition. New Jersey: Pearson.

Mazaheri, E., Richard, M.O. \& Laroche, M. 2011. Online consumer behavior: Comparing Canadian and Chinese website visitors. Journal of Business Research. 64(9):958-965. 
Milan, G.S., Bebber, S., De Toni, D. \&Eberle, L. 2015.Information quality, distrust and perceived risk as antecedents of purchase intention in the online purchase context. Journal of Management Information System \& E-commerce, 2(2):111-129.

Mohanlal, A. 2011. Factors influencing South African Internet users purchasing a product or service online. MBA Thesis. University of KwaZulu Natal.

Morgan, J. 2014. Are you confusing your customers? John Morgan. [Online] Available from: http://johnmichaelmorgan.com/are-you-confusing-your-customers/ [Accessed: 2014-05-29].

Morisson, K. 2014. Social media has changed how consumers shop online. AdWeek.[Online] Available from:http://www.adweek.com/digital/social-media-changed-consumers-shop-onlineinfographic/ [Accessed: 2017-02-21].

Nagra, G. \& Gopal, R. 2013. An study of Factors Affecting on Online Shopping Behavior of Consumers. International Journal of Scientific and Research Publications. 3(6):1-4.

Niranjanamurthy, M. \&Chahar, D. 2013.The study of e-commerce security issues and solutions. International Journal of Advanced Research in Computer and Communication Engineering, 2(7):1-12.

Patel, N. 2011.7 common sales mistakes and how to avoid them.QuickSprout, LLC. [Online] Available from: http://www.quicksprout.com/2011/09/15/7-common-sales-mistakes -and-how-toavoid-them/ [Accessed: 2014-05-29].

Safari, A. 2011.Customers' international online trust - insights from focus group interviews. Journal of Theoretical and Applied Electronic Commerce Research, 7(2):59-72.

Sanje, G. \&Senol, I. 2012.The importance of online behavioural advertising for online retailers. International Journal of Business and Social Science, 3(18):114-121.

Scherbaum, C. \&Schockley, K. 2015.Analysing quantitative data for business and management students. London: Sage.

Shanthi, R. \& Kannaiah, D. 2015. Consumers' Perception on Online Shopping. Journal of Marketing and Consumer Research, 13(2015):14-20.

Sharma, R.S., Alexander, N., Ho, W.C. \&Arasu, P.K. 2013.Functional modelling and analysis of IDM e-tailer platforms. International Journal of E-Business Research, 7(20101):38-59.

Sharkey, U., Scott, M. \& Acton, T. 2010. The influence of quality on e-commerce success: An empirical application of the DeLone and McLean IS success model. International Journal of EBusiness Research, 6(1):68-84.

Song, J., Baker, J., Lee, S. \& Wetherbe, J.C. 2012. Examining online consumers' behavior: A serviceoriented view. International Journal of Information Management, 32(3):221-231.

Snyman, A.N. 2015. Barriers and motivators to online grocery shopping in South Africa: a supply chain perspective. Mcom Thesis. University of South Africa.

Tapson, M.J. 2009.Demographical diversity influence on online shopping orientation and propensity to buy online.Mcom Thesis. Grahamstown: Rhodes University.

Webb, H.W. \& Webb, L.A. 2004.SiteQual: An integrated measure of website quality. Journal of Enterprise Information Management, 17(6):430-440.

Wiid, J. \& Diggines, C. 2013.Marketing research.4th ed. Cape Town: Juta.

Wu, K., Huang, S.Y., Yen, D.C. \& Popova, I. 2012.The effect of online privacy policy on consumer privacy concern and trust. Computers in Human Behaviour, 28(2012):889-897. 